Историография, источниковедение и методы исторического исследования

DOI: 10.31862/2500-2988-2020-11-3-69-84

\title{
Д.И. Горшков
}

Государственный историко-литературный музей-заповедник

А.С. Пушкина,

143050 п. Большие Вязёмы, Одинцовский район, Московская область, Российская Федерация

\section{Проблемы идентификации}

и прочтения портрета велита

2-го полка шволежеров-лансьеров Императорской гвардии Эмиля Сервана

В статье на основе документальных свидетельств и архивных документов проведена идентификация миниатюрного портрета велита 2-го полка шволежеров-лансьеров Императорской Гвардии, хранящегося в собрании института «Anne S.K. Brown Military Collection» и проходящего в каталоге как автопортрет Александра-Жана Дюбуа [Dubois]. Художник Александр-Жан Дюбуа, служивший в полку Красных лансьеров, является автором целого ряда портретов, в том числе известного миниатюрного портрета графини де Берри [de Berry]. В результате исследования матрикулярных регистров всех фурьеров велитовлансьеров за 1810-1815 гг. из собрания Service Historique de la Défense была доказана ошибочность версии о принадлежности данной работы кисти Дюбуа. На основе сравнительного анализа антропологических данных, содержащихся в матрикулярах, было установлено имя изображенного на портрете, - фурьер велитов-лансьеров Эмиль Серван [Servant]. В статье также уделено внимание рассмотрению униформы велитов, включая отдельные детали, и отмечены ее отличия от униформы лансьеров. 
Ключевые слова: Великая армия, французская армия, шволежеры-лансьеры, Императорская гвардия, Александр-Жан Дюбуа-Драонэ, Эмиль Серван, иконография, матрикулярные регистры

Благодарности. Автор выражает признательность и благодарность своим коллегам, помогавшим в поиске иконографии, - Рональду Павли [Ronald Pawly] (бывшему главному редактору журнала «Солдаты Наполеона» [Soldats Napoléoniens], Франция), Петеру Харрингтону [Peter Harrington] (куратору института «Anne S.K. Brown Military Collection»), Од Гобе [Aude Gobet] (руководителю службы исследований и документов Отдела живописи Музея Лувра, Франция).

ДЛЯ ЦИТИРОВАНИЯ: Горшков Д.И. Проблемы идентификации и прочтения портрета велита 2-го полка шволежеров-лансьеров Императорской гвардии Эмиля Сервана // Локус: люди, общество, культуры, смыслы. 2020. Т. 11. № 3. C. 69-84. DOI: 10.31862/2500-2988-2020-11-3-69-84

\section{D.I. Gorshkov}

State Historical and Literary Museum-Reserve of A.S. Pushkin, Bolshiye Vyazyomy, Odintsovsky District, 143050, Moscow Region, Russian Federation

\section{Problems with identification of the portrait of velite of the 2nd Regiment of Chevauleger-lanciers of the Imperial Guard Emile Servant}

The article is based on eye-witness accounts and archival documentsand is aimed to identify miniature protrait of velite of the 2 nd Regiment of Chevauleger-lanciers of the Imperial Guard. It is preserved in Anne S.K. Brown Military Collection Institute and was identified as self-portrait of Alexandre-Jean Dubois. The painter Alexandre Jean Dubois served in the regiment of Red lanciers and was the author of a series of portraits, including the famous miniature portrait of countess de Berry. As a result of research of personal registers of all farrier-velites of lancers for 1810-1815 period in Service Historique de la Défense collection we proved that the identification of this miniature as Dubois work was false. With the help of antropological data 
from personal registers we discovered the name of a person from the portrait. It is farrier-velite Emile Servant. We paid special attention to velite's uniform with all its details and special details which differed it from lancers' uniform.

Key words: Grande Armée, French Army, $2^{e}$ régiment de chevau-légers lanciers de la Garde Impériale, Jean-Alexandre Dubois-Drahonet, Émile Servant, iconography, register (matricule)

Acknowledgments. The author expresses his gratitude to Ronald Pawly, ancien rédacteur en chef de Soldats Napoléoniens, Peter Harrington, Curator - Anne S.K. Brown Military Collection, Aude Gobet, chef du Service Service d'Étude et de Documentation - Département des Peintures, Musée du Louvre.

FOR CITATION: Gorshkov D.I. Problems with identification of the portrait of velite of the 2nd Regiment of Chevauleger-lanciers of the Imperial Guard Emile Servant. Locus: People, Society, Culture, Meanings. 2020. Vol. 11. No. 3. Pp. 69-84. (In Russ.) DOI: 10.31862/2500-2988-2020-11-3-69-84

Неверное прочтение источников часто приводит к многочисленным ошибкам и неточностям, заставляя исследователя вновь и вновь обращаться к нему и искать новые пути решения возникшей проблемы. Подобная ситуация характерна для иконографии, а также для портретной живописи эпохи Первой империи.

Яркий пример последнего постулата - миниатюрный портрет (гуашь, кость, размер без рамки - $6 \times 6$ см, с рамкой $-21 \times 18$ см) велита ${ }^{1}$ 2-го полка шволежеров-лансьеров ${ }^{2}$ Императорской гвардии (рис. 1). C 1962 г. он хранится в собрании института “Anne S.K. Brown Military Collection" (Провиденс, шт. Род-Айленд, США) и с 1990-х гг. значится в каталоге как портрет Александра-Жана Дюбуа [30, p. 83; 31, p. 322].

Начиная с первой работы бельгийского исследователя Рональда Павли (1998), посвященной истории 2-го полка шволежеров-лансьеров, данная миниатюра ошибочно идентифицируется как автопортрет фурьера ${ }^{3}$ Красных лансьеров Александра-Жана Дюбуа [Там же]. В силу ряда причин, рассмотренных ниже, подобное утверждение не выдерживает никакой критики.

${ }^{1}$ Велиты - в Императорской гвардии в 1804-1813 гг. «солдаты особых подразделений ряда гвардии полков; набирались из зажиточных слоев населения, зачислялись в гвардию рядовыми, после прохождения спец. подготовки производились в офицеры армейских полков» [1, с. 112].

${ }^{2}$ Шволежеры-лансьеры - вид легкой кавалерии [1, с. 794].

3 Фурьер (фр. fourrier - 'тот, кто кормит') - в ряде европейских армий нижний чин унтер-офицерского звания, исполнявший должность ротного и эскадронного квартирьера.

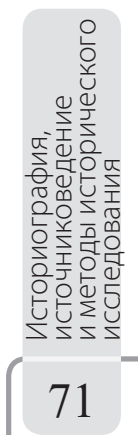




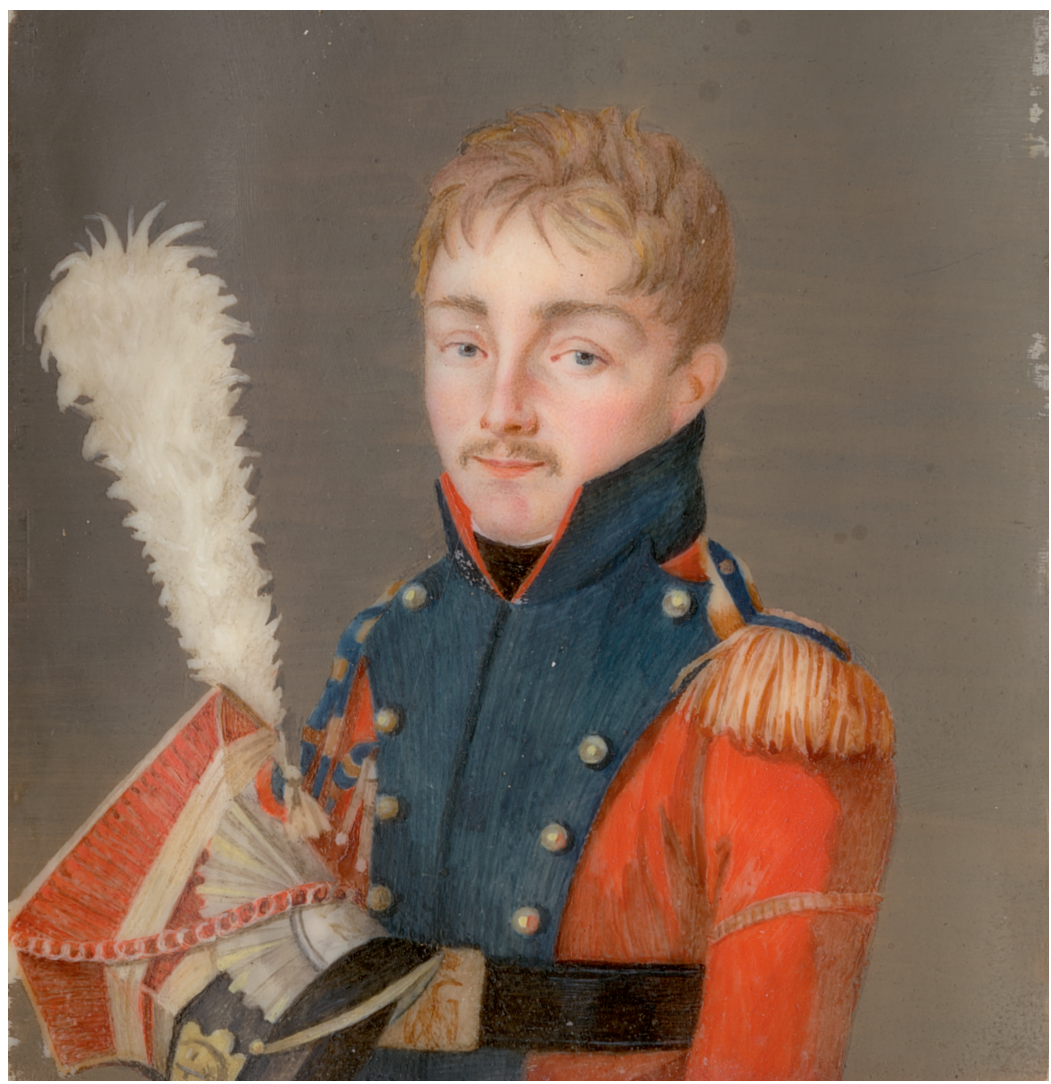

Рис. 1. Французская школа. Миниатюрный портрет фурьера велитов 2-го (голландского) полка шволежеров-лансьеров Императорской гвардии Эмиля Сервана. 1813 г.

Гуашь, кость, размер без рамки $-6 \times 6$ см, с рамкой $-21 \times 18 \mathrm{~cm}$.

"Anne S.K. Brown Military Collection" (Провиденс, шт. Род-Айленд, США)

Начнем с того, что нам известна лишь одна поздняя работа Дюбуа в жанре миниатюрного портрета. Это портрет Марии-Каролины, принцессы Бурбон-Сицилийской, герцогини де Берри (1798-1870) работы 1829 г. [8, p. 5 (16); 35, p. 215 (Pl. 182, fig. 340)]. Безусловно, учитывая высокое качество исполнения портрета герцогини де Берри, его крайне затруднительно сравнивать с обсуждаемым здесь портретом велита - средней, лишенной индивидуальности миниатюрой. К тому же приходится исходить из разных периодов создания этих портретов: 1812-1814 гг. и 1829 г. соответственно. 
К тому же анализ станковых произведений данного художника 1812-1813 гг., его зарисовок того же времени и прочих произведений не позволяет нам говорить о Дюбуа как об авторе миниатюры, поскольку к 1812 г. его можно было считать вполне сложившимся профессиональным художником. Недаром 1 ноября 1812 г. в Музее Наполеона в Париже он уже будет выставлять свои работы: «Портрет женщины» (№ 320) и «Портрет молодого человека» (№ 321) [16, p. 34; 22, p. 10].

Анализ документов, связанных с военной карьерой А.-Ж. Дюбуа в рядах 2-го полка, и прежде всего всех вариантов его матрикулярных регистров ${ }^{4}$, также не подтверждает утвердившуюся версию [3, S. 618; 4, p. 24-25 (80-81); 9, p. 122; 12; 15; 23, p. 200-201; 24, p. 204, 310; 32, p. 66-75; 33, p. 40; 39, p. 50].

Итак, Дюбуа [Dubois] (Александр, Жан), велит (№ 298), родился 31 декабря 1790 г. в Париже (Сена), сын Клода-Жака Дюбуа, торговца, и Анжелик-Виктуар Дюбуа, урожденной Галле [Gallet]. Основываясь на акте о его рождении, можно утверждать, что в его матрикулярных регистрах допущена ошибка, поскольку в акте стоит другая дата 23 декабря 1790 г., улица Сэнт-Онорэ № 378 (нумерация того периода. - Д.Г.), приход церкви Сэн-Жермэн-л’Осеруа. Таинство крещения состоялось на следующий день - 24 декабря 1790 г. ${ }^{5}$ Что же касается антропологических данных, то в его регистре значится следующее: Рост: 1 м 76 см. Лицо: овальное. Лоб: обычный. Глаза: голубые. Нос: обычный. Рот: средний. Подбородок: круглый. Волосы и брови: блондин.

Мальчиком Дюбуа был отдан в Королевскую академию живописи и скульптуры в Париже, где сначала был прикреплен к мастерской Симона Жюльена [Julien] (1735-1800), а впоследствии, видимо, 5 прериаля XII г. Республики (25 мая 1804 г.) определен учеником к ЖануБатисту Реньо [Regnault] (1754-1829). С 1812 г. молодой художник стал выставляться на парижских салонах, а в 1813 г. выпустился из Академии.

25 февраля 1813 г. Александр Дюбуа, проживавший тогда в Париже на улице Святой Маргариты, № 41 [16, р. 34], вступил волонтером в полк Красных лансьеров и был направлен лансьером-велитом

${ }^{4}$ «Матрикулярный регистр... был базовым документом администрации частей. Он отвечал на многочисленные запросы: прежде всего, позволял выявить реальную численность личного состава и бороться с дезертирством, а также давал возможность обеспечить права солдат и их семей. Регистры предоставляли как гражданскую, так и военную информацию по каждому входившему в батальон, в полк, потом в полубригаду человеку, т.е. о солдате и унтер-офицере» [5, p. 25].

${ }^{5}$ Подчеркнем, что часто в многочисленных работах, включая и документы из собрания Отдела исследований и документации (секция живописи) музея Лувр (Париж, Франция), указана неверная дата рождения Александра Дюбуа, не соответствующая ни матрикулярному регистру, ни записи в акте о его рождении, -1791 г.

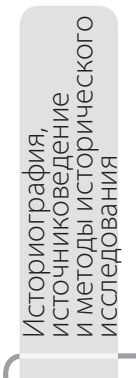


в 10-ю роту; 28 февраля 1813 г. переведен с чином бригадира в 9-ю роту; 1 марта 1813 г. определен вахмистром в 20-ю роту; 1 июня 1814 г. переведен с тем же чином (вахмистр) в 3-ю роту, а 2 августа 1814 г. Дюбуа, находясь в отпуске после болезни, был исключен из полковых списков по причине долгого отсутствия. Спустя несколько месяцев, 15 марта 1815 г., он вернулся в полк, преобразованный по королевскому ордонансу от 21 июня 1814 г. в Королевский корпус лансьеров Франции, и 30 марта был определен в него сверхштатным вахмистром под № 730; 1 апреля 1815 г. Дюбуа изъявил желание войти в новый, преобразованный полк; вошел под № 200 в состав нового полка шволежеров-лансьеров Императорской гвардии, образованного по декрету от 8 апреля 1815 г.; уволен с военной службы 21 апреля 1815 г.

19 ноября 1817 г. Дюбуа женился на девице Элизабет-Корнели Драонэ [Drahonet], дочери покойного Пьера Драонэ и Франсуаз Драонэ, урожденной Турнэ [Tournay]. Именно после 1817 г. Дюбуа стал подписываться как Дюбуа-Драонэ, присоединив таким образом к своему имени девичью фамилию своей жены. Традиционно Александра-Жана Дюбуа даже в специализированных работах ошибочно обозначают как родственника командующего майора (позже генерал-майора) во 2-м полку шволежеров-лансьеров Императорской гвардии Шарля-Мари-Жозефа Дю Буа (или Дюбуа) де Ферьэра (1772-1829) [7, р. 151], что, безусловно, в корне неверно. Между тем во избежание повторения этой ошибки, мы по возможности далее будем давать двойную, хотя и более позднюю, фамилию художника, разделяя таким образом разных исторических персонажей - командующего майора и велита. Опуская этапы жизни Дюбуа-Драонэ периода 2-й Реставрации и начала Июльской монархии, скажем лишь, что он скончался 30 августа 1834 г., в 2 часа утра в своем доме на улице Морепа, № 39 в Версале и был погребен на версальском кладбище Нотр-Дам, улица Мисьонэр (Миссионеров).

Возвращаясь к идентифицируемому портрету, отметим, что на нем действительно изображен фурьер велитов 2-го полка шволежеров-лансьеров Императорской гвардии, о чем говорит нашивка на его левом плече. Особо подчеркнем, что в кавалерии Императорской гвардии, в отличие от армейской кавалерии, не существовало чина фурьер-бригадира $[10 ; 11 ; 19 ; 26$, р. 132-133; 29; 37, p. 20-23], несмотря на ряд ошибочных положений в литературе подобной тематики, особенно научнопопулярного толка [21, p. 47]. Основываясь на приведенных выше данных из матрикулярных регистров Дюбуа-Драонэ, можно заключить, что фурьером художник никогда не был, тогда как изображенный на правом плече аксельбант явно свидетельствует о том, что перед нами фурьер, поскольку изначально при организации полка и вооружении 
его пиками фурьерам пика не полагалась; аналогичная ситуация сложилась и в 1-м (польском) полку шволежеров-лансьеров. Напомним, что с появлением пики в рядах сначала польских шволежеров после кампании 1809 г., а потом и Красных лансьеров аксельбант стал крепиться на левом плече. Что же касается бригадиров, то до 1813 г. все они поголовно вооружались пиками, и только в начале 1813 г., после поражения французской армии в России, пика останется лишь у бригадиров, входивших в состав первых рядов каждой роты. А Дюбуа-Драонэ, несший службу именно в первых рядах, как раз имел на вооружении пику [38, p. 14-16].

В связи с этим было принято решение полностью проверить матрикулярные списки фурьеров велитов-лансьеров за весь период существования 2-го полка, с 1810 по 1815 г. В данном случае мы основывались на антропологических данных изображенного на картине человека, и прежде всего цвете его глаз: серые или голубые (конечно же, учитывались утрата красочного слоя миниатюры и возможное изменение цвета под действием ультрафиолета). Благодаря данному ограничению осталось шесть кандидатов, сравнительный анализ антропологических данных которых показал, что единственным человеком, кто полностью подходит на эту роль, может быть только фурьер велитов-лансьеров Эмиль Серван [Servant]. Выяснилось, что фурьер Шарль (Карл) Дупхоф (или на французский манер Дюфоф) [Duphoff] имел большой нос и заостренный подбородок [39, р. 63], у фурьеров Эрнста Фредерика Теофиля Шрёдера [Schroeder] и Илэра Доннеса [Donnès] были полные лица и приплюснутые носы [Там же, р. 42, 50], а у бригадира Жозефа-Франсуа-Анжа Усce [Housset] одной из отличительных черт являлся круглый подбородок с ямочкой [Там же, р. 40]. Фурьер же Клод-Франсуа Бидо [Bidaut] был не только обладателем длинного носа, круглого и вытянутого подбородка. В матрикулярных списках значится, что 5 апреля 1814 г. он стал кавалером ордена Почетного легиона, фурьерские же нашивки были им получены 28 мая 1813 г. при переводе в 4-ю роту [Там же, p. 51]. Антропологические же данные упомянутого выше Сервана, между тем, полностью соответствовали чертам рассматриваемого портрета [Там же, р. 37].

Серван (Эмиль), велит (№ 220), родился 23 декабря 1794 г. (3 нивоза III г. Республики) в Сен-Мэксан (Дё-Севр), сын покойного Шарля Сервана и Мари-Эстер Серван, урожденной Кэйо [Cayault]. Рост: 1 м 80 см. Лицо: овальное. Лоб: круглый. Глаза: серые. Нос: обычный. Рот: средний. Подбородок: круглый. Волосы и брови: темно-русые. Поступил на службу во 2-й полк шволежеров-лансьеров Императорской гвардии 10 декабря 1812 г. (9-я рота 5-й эскадрон); определен фурьером

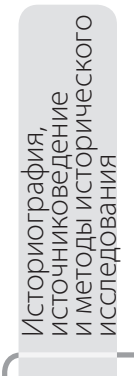


в 10-ю роту 3 марта 1813 г.; 24 апреля 1813 г. перешел во 2-ю роту; скончался 11 августа 1813 г.

Новое обращение к представленному здесь изобразительному материалу и его анализ, с одной стороны, позволили определить подлинного человека прошлого, а с другой - уточнили военную карьеру видного французского художника эпохи 2-й Реставрации Дюбуа-Драонэ. Кроме того, верное прочтение миниатюрного портрета Сервана и сравнение его со всей известной иконографией дает возможность скорректировать устоявшиеся представления об униформе велитов Красных лансьеров в период их существования [7, р. 141 (5), 151; 27, p. 448-449; 34, p. 335 (19), 338].

Основные отличия униформы велитов от лансьеров 2-го полка заключались в следующих деталях. Велиты носили желто-синие аксельбанты, а их унтер-офицеры - сине-золотые. Соотношение синих и золотых шнуров, составлявших аксельбант, менялось в зависимости от чина: у фурьеров и вахмистров - 1/3 золотых к 2/3 синих шнуров; у старших вахмистров - 2/3 золотых к 1/3 синих шнуров.

Не менее важно отметить, что, судя по анализируемому портрету (см. рис. 1) и портрету майора Дюбуа работы Дюбуа-Драонэ (рис. 2), поля эполет также различались: у лансьеров они желтые, у велитов - синие. При этом, опираясь на данные изобразительные источники, можно говорить, что с середины 1813 г. унтер-офицеры (фурьеры, вахмистры и старшие вахмистры) Красных лансьеров, а не только их велиты, в отличие от унтер-офицеров 1-го польского полка, не имели так называемой смешанной желто-золотой бахромы на эполетах [28]. Таким образом, сама бахрома эполет, верхний их валик и галун, идущий по краю поля эполет, были полностью золотыми. Если же все-таки бахрома и была смешанной, то, видимо, только у бригадиров 2-го полка. Правда, последнее предположение нам представляется менее вероятным.

Рис. 2. Александр-Жан Дюбуа-Драонэ (1790-1834). Портрет командующего майора (позже генерал-майор) во 2-м полку шволежеров-лансьеров Императорской гвардии Шарля-Мари-Жозефа Дю Буа, или Дюбуа де Ферьэр (1772-1829), в полной парадной форме, на фоне отступления из России в 1812 г. Дата написания: июнь 1813 г. или январь-март 1814 г. Х., м., 2,52 × 1,74 м. Дар вдовы графа Альбера дю Буа. Фонд ван дер Бюрха, Укрепленный феодальный замок Экосинн-Лялэн (Бельгия) - Fondation van der Burch, Château-Fort, Ecaussinnes-Lalaing

(c) photo Peter Maes, Ronald Pawly 
лОКУС: люди, общество, культуры, смыслы. 2020. Т. 11. № 3

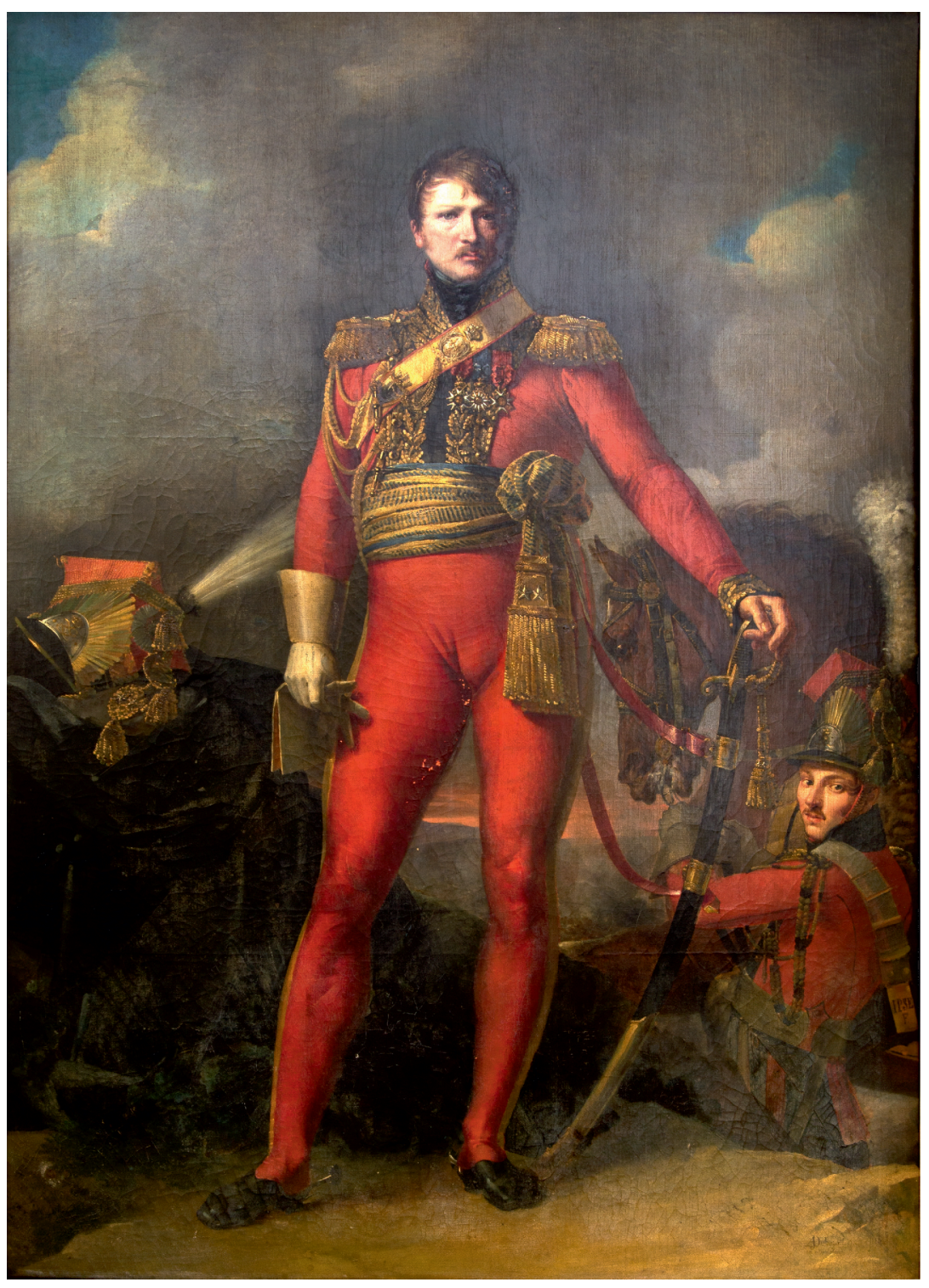

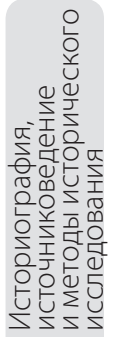


Также можно утверждать, что в 1813-1814 гг. унтер-офицерский корпус (фурьеры, вахмистры и старшие вахмистры) во всем голландском полку носил шапки офицерского образца, но, в отличие от офицеров, с общевойсковыми кокардами. В этой связи неудивительно, что и Дюбуа-Драонэ, и Эмиль Серван представлены в шапках с золотыми этишкетами ${ }^{6}$ и белыми султанами, тогда как шапки простых велитов украшались, во-первых, желто-синим этишкетом и такого же цвета шнурком, идущим по углам и верху самой шапки, а во-вторых, имели черные султаны с белым верхом. Данная информация позволяет также более точно идентифицировать шапку из собрания музея Ампери (Салон-де-Прованс, депо (филиал) Музея Армии, Париж, Франция), которая полностью соответствует данному описанию, за исключением золотого галуна по верху кожаного околыша [6, p. 126 (1)]. Эта особенность дает возможность отнести шапку к образцам, использовавшимся бригадирами велитов Красных лансьеров. И, наконец, последняя отличительная деталь униформы велитов - черная небеленая экипировка (портупея, перевязь лядунки и панталер) и, по всей видимости, темляк сабли. Традиционно в историографии, начиная с работы Бюкуа, их экипировку описывают как белую [7, p. 141 (5), 151]. Данное ошибочное положение сформировалось под влиянием некритического отношения к портрету майора Дюбуа работы Дюбуа-Драонэ, который в период и 1-й Реставрации, и «Ста дней» многократно переписывался, включая и экипировку самого Александра-Жана.

Обратимся к портрету Шарля-Мари-Жозефа Дю Буа (или Дюбуа де Ферьэр) (1772-1829). Авторская подпись (внизу, с правой стороны холста): A. J. Dubois, S. = off. / dumême Rég. ${ }^{t}$ («А.-Ж. Дюбуа, унтерофицер в том же полку»). Также имеется надпись на латыни на боку лядунки лансьера, держащего под уздцы лошадь Дюбуа: IPSE F. (ipse fecit) («собственноручно исполнил»). На обороте холста имеется надпись, сделанная орешковыми чернилами, вероятнее всего, самим художником:

Le Baron Charles Marie Joseph DUBOIS, né le 22 Octobre 1772

$<\ldots>$ (не читается, т.к. текст расположен под перемычкой подрамника. - Д.Г.)

Au 2. ${ }^{\text {ème }}$ Reg. ${ }^{\text {ent }}$ de Chevau-L [é]gers Lanciersdela Gar. ${ }^{\text {de }}$ Imp.

Ayant 25 ans de Service Actif sans Interruption

14 Campagnes et trois blessures

Promu au Grade supérieur au Champ de batai[lle]

A Castricum

\footnotetext{
6 Этишкет - украшение в виде плетеной шнуровой подвески на кивере или на строевой шапке [1, с. 877].
} 
Ayant eu deux fr[è]res tués au Champ d'honneur

Peint

par Alex ${ }^{\text {dre }}=$ Jean DUBOIS, était protégé de

$N .=$ aux Acad. Imp. à Paris, Elève de M. REGNAULT

Né le $25 X^{\text {bre }} 1790$, Ayant exercé la

peinture jusqu'à 23 Ans

Juin 1814 (в оригинале цифра 3 исправлена на 4. - Д.Г.)

(«[Портрет] Барона Шарля Мари Жозефа Дюбуа, родившегося 22 октября 1772 г. <..> во 2-м полку шволежеров-лансьеров Императорской гвардии, имеющего 25 лет действительной и беспрерывной военной службы, 14 кампаний и три ранения, получившего чин старшего офицера на поле сражения при Кастрикюме и потерявшего на поле чести убитыми двух братьев, написан Александром-Жаном Дюбуа, по протекции N [определенным] в Императорские Академии в Париже учеником к г-ну Реньо, появившимся на свет 25 декабря 1790 г., практиковавшимся в живописи до 23 лет, июнь 1814 г.»).

Портрет был заказан Дюбуа де Ферьэром либо по случаю возведения его в титул барона Империи (26 ноября 1813 г.) и получения им жалованной грамоты дворянства 24 января 1814 г., либо в связи с награждением кавалерским крестом ордена Почетного легиона под № 34871 14 апреля 1813 г. [13]. В декабре 1814 - феврале 1815 г. (в источниках приведены разные даты награждения Дюбуа де Ферьэра орденом Святого Людовика) данный портрет был окончательно переписан. Также ранее были добавлены элементы, указывающие на чин генерал-майора, который был присвоен изображенному 24 ноября 1814 г. [14].

Итак, Дюбуа-Драонэ переписал мундир своего шефа и добавил шитье на лацканы, воротник, обшлага, а также вместо изображенного до этого галуна по верху околыша шапки художник показал генеральское шитье. Кроме того, на рассматриваемой фигуре появились звезды на эполетах, темляке, ракетках этишкета и на бляхе шапки.

В этот же период была записана и парадная офицерская портупея Красных лансьеров, замененная золотым с синими полосками шарфом генерал-майора. Императорская символика на перевязи лядунки (орел и литера $N$ ) и на бляхе шапки (коронованная литера $N$ ) также были заменены королевским картушами, литерой $L$ и коронованной королевской монограммой JL. K сожалению, приходится констатировать, что данный портрет требует серьезной научной реставрации. Видимо, по этой причине сейчас на шапке Дюбуа де Ферьэра можно видеть первоначальную трехцветную сине-красно-белую имперскую кокарду вместо королевской белой кокарды.

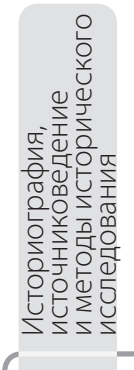


Подчеркнем, что перерабатывался и кавалерский крест ордена Почетного легиона, замененный на офицерский крест ордена (добавлена розетка на орденскую петлицу и записаны серебряные элементы на самом кресте: корона и шарики на концах лучей креста). Напомним также, что 24 октября 1814 г. Дюбуа де Ферьэр был награжден офицерским крестом ордена Почетного легиона. Вероятно также, что из-за трудностей при реорганизации элементов композиции Дюбуа-Драонэ не стал переписывать наградной ряд Дюбуа де Ферьэра в соответствии с новыми королевскими правилами, как и добавлять знак лилии, полученный его шефом 2 мая 1814 г. [20, p. 116 (92), 177]. В противном случае он должен был показать первым крест ордена Святого Людовика, потом шел бы знак лилии, за ним орден Почетного легиона и после орден Воссоединения, кавалером которого Дюбуа де Ферьэр стал 7 марта 1812 г. По королевскому ордонансу от 19 июля 1814 г. каждый, кто получил орден Воссоединения, официально имел право продолжать его носить, в отличие от орденов королевств Вестфалии и Испании [25, p. 209].

Любопытно, что Дюбуа де Ферьэр показан в перчатках с крагами и в черном галстуке, что позволяет определить вид его формы как полную зимнюю парадную. Оголовье лошади Дюбуа де Ферьэра полностью соответствует образцам, использовавшимся в 1-м польском полку шволежеров-лансьеров Императорской гвардии, что подтверждает рисунок периода Русской кампании 1812 г. рисовальщика при итальянском топографическом бюро 4-го армейского корпуса Альбрехта Адама [Adam] [2]. Что же касается фигуры, держащей за поводья лошадь Дюбуа де Ферьэра, то это сам автор полотна Александр-Жан ДюбуаДраонэ, на что указывает надпись на латыни на боку его лядунки: IPSE F. (ipse fecit) («собственноручно исполнил») [32, p. 66-72].

Как указывалось выше, фигура Дюбуа-Драонэ также подверглась определенной трансформации. Во-первых, Дюбуа-Драонэ здесь показан не вахмистром велитов Красных лансьеров, а уже сверхштатным вахмистром лансьеров Королевского корпуса лансьеров Франции [9, p. 122]. На это указывает его переписанная экипировка. Так, вместо черной кожи, являвшейся отличительным знаком велитов, здесь мы видим традиционную белую перевязь лядунки и белую с такими же пасовыми ремешками портупею. Во-вторых, на налобнике шапки коронованная литера $N$ заменена на королевский картуш с тремя лилиями в центре. Также аксельбант на левом плече Дюбуа-Драонэ говорит нам о том, что портрет был написан все-таки в начале 1814 г., а белый султан, - что перед нами унтер-офицер.

Данный портрет был выставлен Александром-Жаном Дюбуа-Драонэ (улица Монтескьё, № 8) 1 ноября 1814 г. в салоне, проходившем в Королевском музее искусств, вместе с другими его произведениями под 
следующими номерами: 1406 - Полноростовой портрет г-на барона *** (Дюбуа. - Д.Г.), полковника королевских лансьеров [Portrait en pied de M. Le baron de *** Colonel des lanciers royaux]; 1407 - Также (полноростовой портрет. - Д.Г.) Мад[ам] баронессы *** (Дюбуа. - Д.Г.) с ее детьми [Idem de Mad. La baronne de ***, avec ses enfants]; 1408 - Также (полноростовой (?) портрет. - Д.Г.) Г-на Н. (речь идет, вероятно, о Рене-ТеофилеМари-Иасинте (Гиацинте) Лаэннеке [Laënnec] (1781-1826). - Д.Г.), докт[ора] медицины [Idem de M.H., doct. en médecine]; 1409 - Также (полноростовой (?) портрет ${ }^{7}$ - Д.Г.) Г-на дивизионного генерала, графа Р. *** (речь идет о Шарле-Жозефе Рандоне де Мальбуассьэре, графе де Пюлли [Randon de Malboissière, comte de Pully] (1751-1832). - Д.Г.) [Idem de M. Le général de division, comte de P. ***] [17, p. 137].

\section{$* * *$}

Таким образом, использование критериев антропологических и анатомических признаков, указанных в матрикулярных регистрах, позволило объективно оценить достоверность отображения признаков внешности изображенного лица. Новая идентификация миниатюрного портрета велита 2-го полка шволежеров-лансьеров Императорской Гвардии, хранящегося в собрании института «Anne S.K. Brown Military Collection», помимо обозначенных выше моментов, позволила заполнить определенные лакуны, связанные с реконструкцией коллективного портрета велитов 2-го полка шволежеров-лансьеров Императорской гвардии в 1811-1814 гг. Это же, в свою очередь, дает возможность в дальнейшем не только лучше ориентироваться в эволюции эмблематических форм милитарной среды, но смотреть более взвешенно на визуальные репрезентации власти в период апогея существования 1-й Империи, выводя исследователя на новый уровень, позволяющий ставить новые вопросы, связанные с нациостроительством и отражением данного процесса в униформе «человека воюющего». Эволюция вооруженных сил Французской империи, победы, одержанные в ходе наполеоновских войн, не могли не оставить свой след на военном обмундировании, что нашло отражение как в военном портрете, так и в портретной миниатюре.

\footnotetext{
${ }^{7}$ Дело в том, что Аукционный дом Секвана в 2018 г. выставил на торги погрудный портрет генерала Пюлли работы Дюбуа-Драонэ [36, p. 5 (Lot. 32)]. Несмотря на отсутствие имени в каталоге данного аукциона, исходя из изображенных наград, мундира и его элементов, нами было установлено, что речь идет именно о Пюлли. Данный портрет, как и портрет майора Дюбуа, переписывался в 1815 г., и, по всей вероятности, именно он был выставлен в Салоне 1814 г. в Париже [18, р. 331-332]. Видимо, в каталожное описание вкралась ошибка, и данная картина была обозначена как полноростовой портрет. Но мы не исключаем, что существует и полноростовой портрет этого генерала. В этой связи здесь приводятся обе версии.
}

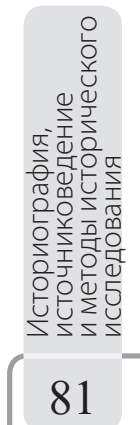


Библиографический список / References

1. Отечественная война 1812 года: Энциклопедия / Под ред. В.М. Безотосного. М., 2004. [Otechestvennaya voyna 1812 goda [Patriotic War of 1812 (French invasion of Russia)]. Encyclopedia. V.M. Bezotosnyy (ed.). Moscow, 2004.]

2. Adam Albrecht (1786-1862). Feldzug von 1809. Staatliche Graphische Sammlung München, Inv. Nr. 18782-072 Z; Bleistift; Blattmaß: $208 \times 271 \mathrm{~mm}$.

3. Allgemeines Lexikon der bildenden Künstler von der Antike bis zur Gegenwart: unter Mitwirkung von 300 Fachgelehrten des in- und Auslandes. Begründet von U. Thieme und F. Becker. Bd. IX (Delaulne-Dubois). Leipzig, 1913.

4. Baard H.P. Catalogue des tableaux et dessins du Musée municipal Frans Hals à Haarlem. [s. 1.], 1914.

5. Bertaud J.-P., Roucaud M. Registres matricules des sous-officiers et hommes de troupe des unités d'infanterie de ligne et d'infanterie légère de la Révolution, Répertoire de la sous-série $17 \mathrm{Y}^{\mathrm{c}}$. Vincennes, 2009.

6. Bourgeot V. Les trésors de l'Empéri. L'armée de Napoléon. La collection Raoul et Jean Brunon. Préface du général Robert Bresse, directeur du Musée de l'Armée. Nouvelle édition. Annecy-le-Vieux, 2009.

7. Bucquoy E.-L. Les uniformes du Premier Empire. La Garde impériale / Réédité par le Lt.-Cl. L.-Y. Bucquoy et G. Devautour. T. II (Troupes à cheval). Paris, 1977.

8. Catalogue des miniatures par Cotes, Dubois-Drahonet, Dubourg... [et al.] appartenant à monsieur $\mathrm{X}$, et dont la Vente aura lieu à Paris hôtel Drouot, sale $\mathrm{N}^{\mathrm{o}}$ 11, le mercredi 25 mars 1914 / [expert]: $\mathrm{M}^{\mathrm{r}}$ Mannheim. Paris, 1914.

9. Corps royal de chevau-légers lanciers de France, ci-devant $2^{\mathrm{e}}$ régiment de chevau-légers lanciers delagarde impériale, 21 juin 1814-20 mars 1815 (matricules : 1 à 735). S.H.D./GR, Sous-série $20 \mathrm{Y}^{\mathrm{c}} 165$.

10. Décret du 6 avril 1807 (copie). S.H.D./GR, Sous-série $X^{\mathrm{ab}} 41$.

11. Décret du 13 septembre 1810 (copie). S.H.D./GR, Sous-série $X^{\mathrm{ab}} 42$.

12. Dubois (1781-1794). Archives de Paris. Fichiers de l'état civil reconstitué du XVI ${ }^{\mathrm{e}}$ siècle à 1859 V3E/N 775.

13. (Dubois, Charles, Marie, Joseph). C.A.R.A.N. LH/269/58.

14. (Dubois, Charles, Marie, Joseph). S.H.D./GR, Sous-série $8 \mathrm{Y}^{\mathrm{d}} 1863$.

15. (Dubois-Drahonet (Alexandre Jean), 1791-1834) in Musée du Louvre. Service d'Étude et de Documentation. Département des Peintures.

16. Explication des ouvrages de peinture et dessins, sculpture, architecture et gravure des artistes vivans, exposés au Musée Napoléon, le $1^{\text {er }}$ novembre 1812. Paris, 1812.

17. Explication des Ouvrages de Peinture et Dessins, Sculpture, Architecture et Gravure des Artistes Vivans, Exposés au Musée Royal des Arts, le $1^{\mathrm{er}}$ Novembre 1814. Paris, 1815.

18. Fanet V. Le $1^{\mathrm{er}}$ Régiment des Gardes d'Honneur (suite). Carnet de la Sabretache. 1914. № 258 (Juin). $3^{\text {ème }}$ Série.

19. Garde Impériale. $2^{\text {ème }}$ Régiment de Chevau-Légers Lanciers. Organisation du Régiment, le 21 septembre 1810. S.H.D./GR, Sous-série X ${ }^{\mathrm{ab}} 42$.

20. Hofstetter B., Plantade P. Autissier et le portrait miniature romantique en Belgique [exposition, Galerie de la Kredietbank, du 19 février au 19 avril 1998]. Brussel, 1998. 
21. Jouineau A. Officiers et soldats de la Garde impériale : 1804-1815. T. III (Les troupes à cheval, 1804-1815 : Mameluks, régiments de chevau-légers, gendarmerie d'élite). $2^{\text {ème }}$ partie. Paris, 2005.

22. Lacour P., Delpit J. Catalogue des tableaux, statues, etc., du musée de Bordeaux. Bordeaux, 1856.

23. La Nouvelle Athènes : haut lieu du Romantisme : [exposition, Paris, Mairie du $9^{\mathrm{e}}$ arrondissement, 18 octobre -2 décembre 2001, Paris, Fondation Taylor, 7 décembre 2001 - 10 février 2002] / [organisée par 1'] Action artistique de la Ville de Paris ; sous la dir. de Bruno Centorame... ; réalisée par Bruno Centorame, Valérie Chiche et Georgina Letourmy ; avec la collab. de Béatrice de Andia, Sandrine Arnold Folpini, Baudoin de Baillet-Latour... [et al.]. Paris, 2001.

24. Lemoine-Bouchard N. Les peintres en miniature : actifs en France, 1650-1850. Paris : Amateur, 2008.

25. Liévyns A. Verdot J.-M. Begat P. Fastes de la légion-d'honneur : biographie de tous les décorés accompagnée de l'histoire législative et réglementaire de l'ordre. T. 4. Paris, 1845.

26. Margueron L.-J. Campagne de Russie. Vol. 1. Paris, [s.a.].

27. Martin Y. La Garde impériale et ses uniformes / illustrations de Henry Boisselier ; preface du général Michel Hanotaux. Paris, 2008.

28. Mundur Wielkiwachmistrzapułku Lekkokonnego polskiego gwardii cesarza Napoleona I, lata 1807-1814. Muzeum Wojska Polskiego w Warszawie, nry inw. 24526x, 24524x, 52727.

29. Rapport fait au Ministre, le 11 octobre 1810. S.H.D./GR, Sous-série $X^{\text {ab }} 42$.

30. Pawly R. Les Lanciers Rouges. Erpe, 1998.

31. Pawly R. Les Lanciers Rouges de la Garde. Historique du $2^{\mathrm{e}}$ Régiment de Chevau-légers Lanciers de la Garde Impériale. Les frères de Stuers au service de Napoléon - $\mathrm{N}^{\mathrm{o}}$ 2. Bruxelles, 2008.

32. Pawly R. Alexandre-Jean Dubois, peintre chez les Lanciers Rouges. Revue Napoléon $(R N)$ - Nouvelle Série. 2016. N 23 (Décembre). P. 66-75.

33. Régiment de chevau-légers lanciers, créé par décret du 8 avril 1815 et formé de l'ex-corps royal des lanciers de France, 8 avril 1815 - 22 décembre 1815 (matricules : 1 à 1 608). S.H.D./GR, Sous-série $20 \mathrm{Y}^{\mathrm{c}} 166$.

34. Rousselot L. L'armée française. Introduction Yves Martin. Paris, 2009.

35. Schidlof L.R. La miniature en Europe aux XVI ${ }^{\mathrm{e}}, \mathrm{XVII}^{\mathrm{e}}, \mathrm{XVIII}^{\mathrm{e}}$ et $\mathrm{XIX}^{\mathrm{e}}$ siècles. Graz, 1964.

36. Sequana, Maison de vente aux enchères. Paris-Rouen. Rouen, Samedi 17 novembre 2018 à 14 h 00. Livres-Papiers-Photos-Tableaux-Armes blanchesArmes à feu-Uniformes-Équipements-Figurines-Aviation. Experts : Danyela Petito. Rouen, 2018.

37. Supplément à la correspondance de Napoléon $\mathrm{I}^{\mathrm{er}}$ : l'Empereur et la Pologne. Publié par Adam Skalkowski. Paris, 1908.

38. [V.] Le double armament des lanciers sous le premier Empire. Carnet de la Sabretache. 1893. № 1. P. 12-20.

39. Vélites placés à la suite du $2^{\mathrm{e}}$ régiment de chevau-légers lanciers de la Garde Impériale, 21 août 1811 - 29 mars 1814 (matricules : 1à 545). S.H.D./GR, Soussérie $20 \mathrm{Y}^{\mathrm{c}} 163$. 
O6 авторе / About the author

Горшков Дмитрий Игоревич - кандидат исторических наук; старший научный сотрудник, Государственный историко-литературный музей-заповедник А.С. Пушкина, п. Большие Вязёмы, Одинцовский район Московской обл.

Dmitriy I. Gorshkov - PhD in History; Senior Research Associate, State Historical and Literary Museum-Reserve of A.S. Pushkin, Bolshiye Vyazyomy, Odintsovsky District, Moscow Region

E-mail: le84e-regiment@mail.ru 